\title{
A new chemical formulation for control of dental unit water line contamination: An 'in vitro' and clinical 'study' Lucio L Montebugnoli*1 and Giovanni G Dolci ${ }^{2}$
}

\author{
Address: ${ }^{1}$ Department of Oral Science, University of Bologna, Italy and ${ }^{2}$ Dental Clinic, University "La Sapienza" Rome, Italy \\ E-mail: Lucio L Montebugnoli* - montebu@alma.unibo.it; Giovanni G Dolci - castellini@castellini.com \\ *Corresponding author
}

Published: II February 2002

BMC Oral Health 2002, 2:1

This article is available from: http://www.biomedcentral.com//472-683I/2//

(c) 2002 Montebugnoli and Dolci; licensee BioMed Central Ltd. Verbatim copying and redistribution of this article are permitted in any medium for any purpose, provided this notice is preserved along with the article's original URL.
Received: 5 October 2001

Accepted: II February 2002

\begin{abstract}
Background: Water delivered by dental units during routine dental practice is highly contaminated. The aim of this study is to evaluate the efficacy of a new chemical solution flushed through Dental Unit Water Lines (DUWL) for the control of contamination inside dental units.
\end{abstract}

Materials and methods: Six old dental units equipped with a device designed to automatically flush disinfecting solutions through the water system (Castellini Autosteril) were selected. Water samples from DUWL effluents were collected in each dental unit for 10 randomly selected days, before and after a 5 minute DUWL disinfecting cycle with TetraAcetylEthileneDiamine (TAED) and persalt (Ster4spray produced by Farmec spa, and distributed by Castellini spa). Water samples were plated in R2A Agar and cultured at room temperature for 7 days, and the total number of heterotrophic microorganisms counted and expressed in $\log _{10} \mathrm{CFU} / \mathrm{mL}$ A general linear model was fitted and multiple regression ANOVA for repeated measures was used for the statistical analysis.

Results: The mean contamination in DUWL effluent at baseline was $5.45 \pm 0.35 \mathrm{CFU} / \mathrm{mL}$ (range 4.79 to $5.93 \mathrm{CFU} / \mathrm{mL}$ ). When water samples were tested "in vitro" against the chemical, no growth of heterotrophic bacteria was detected after a 5 minute contact in any of the water samples tested. After undergoing a 5 minute disinfecting cycle with the chemical, DUWL mean contamination in water effluents was $2.01 \pm 0.32 \mathrm{CFU} / \mathrm{mL}$ (range 1.30 to $2.74 \mathrm{CFU} / \mathrm{mL}$ ) (significant difference with respect to baseline).

Conclusions: An inbetween patient disinfecting procedure consisting of flushing DUWL with TAED and persalt equivalent to $0.26 \%$ peracetic acid could be useful in routine dental practice for cross-contamination control.

\section{Background}

It has been known for more than 30 years that water delivered by dental units during routine dental practice is highly contaminated by numerous species of pathogen and non-pathogen microorganisms which enter dental units retracted up from the oral cavity of patients under- going dental treatment or delivered by incoming municipal water, the so called heterotrophic bacteria [1-3]. Inside dental units, heterotrophic bacteria persist in DUWLs growing as a multispecie biofilm on the inner surface and continuously supplying dental unit water system. In 1996 American Dental Association established a goal for 
dental water to contain no more than 200 Colony Forming Units (CFU) /mL (2.3 in $\log _{10} \mathrm{CFU} / \mathrm{mL}$ ) of heterotrophic unfiltered output [4] Several methods have been suggested by which the DUWL contamination by heterotrophics might be kept under this limit and flushing protocols or chemical treatment are some of the options available to dentists $[5,6]$.

Among chemicals now available, peracetic acid is one of the most powerful biocidal agent with a rapid and broad spectrum biocidal activity and could be a useful chemical for the purpose of controlling DUWL contamination $[7,8]$, although, as delivered, it has a series of side-effects which have limited its use in dentistry [9-12].

In recent years, a new chemical formulation (TetraAcetylEthyleneDiamine in association with persalt) has been proposed as a non hazardous means of generating peracetic acid in situ in the absence of preformed peracetic acid side-effects $[13,14]$.

The aim of this study was to evaluate the efficacy of the chemical to control DUWL bacterial contamination by heterotrophics both when tested "in vitro" and when flushed into DUWL.

\section{Materials and methods}

We selected for use in this study 6 dental units (Castellini Logos), all connected to municipal water and that had been in daily use for approximately 1 year. None of the selected units had ever been treated for removal of biofilm or reduction of planktonic bacteria. All dental units were equipped with a device designed to automatically flush disinfecting solutions through the water system (Castellini Autosteril).

a) DUWL contamination at baseline: a water sample (2 mls) was recovered in the morning before working for 10 randomly selected days from the high-speed handpiece line of each dental unit (60 samples). Samples were collected into a sterile tube added with filter-sterilized sodium thiosulphate at a final concentration of $18 \mu \mathrm{g} / \mathrm{ml}$ to oppose the growth-inhibiting effects of residual chlorine. Two split samples of each were made; the first split sample served to evaluate DUWL contamination at baseline.

b) DUWL contamination following "in vitro" contact with Ster4spray: the second split sample was used for the purpose. Ster4spray (produced by Farmed spa and distributed by Castellini spa Italy) is a fine powder containing a binary active system (TetraAcetylEthyleneDiamine and sodium perborate) which is activated by dissolving in water at a initial temperature of $35^{\circ} \mathrm{C}$ to form peracetyl ions at $\mathrm{pH} 8$, equivalent to $0.26 \%$ peracetic acid ensuring stable concentration up to 24 hours. The active is completely biodegradable and degrades to acetic acid, oxygen and water [14]. One part of each water sample was tested against nine parts of disinfectant. After five minute of contact time, one $\mathrm{mL}$ of the mixture was rapidly added to $9 \mathrm{~mL}$ of the recovery/neutralizer broth (3\% polysorbate $80,0.1 \%$ L-histidine, $0.3 \%$ lecithin, $0.5 \%$ sodium thiosulphate in phosphate buffer $25 \mathrm{~N}$ ) to prevent further inactivation taking place.

c) DUWL contamination after a disinfecting cycle with Ster4spray flushed through DUWL by Autosteril: after collecting samples at baseline, each dental unit underwent (each morning for 10 days) a disinfecting cycle with Ster4spray consisting of flushing DUWLs with the disinfectant and washing it for 2 minutes after a 5 minute contact, and a further water sample was collected immediately after each cycle into a sterile tube added with filter-sterilized sodium thiosulphate.

Water samples (at baseline and after either "in vitro" disinfecting tests or "inside dental unit" disinfecting cycles) were plated in R2A Agar within 3 hours of collection and cultured at room temperature for 7 days, and the total number of heterotrophic microorganisms counted. All absolute counts were converted to $\log _{10}$ values. This laboratory procedure has been recognized to be the best procedure to collect most of heterotrophic bacteria from DUWL [15-17].

A general linear model was fitted and multiple regression ANOVA for repeated measures was used to evaluate differences in CFU/mL between dental units, times (baseline and after disinfecting cycles) and the interaction of dental units $\times$ time; the Bonferroni t test was applied for significant values as a multiple-comparison t-test. The statistical analysis performed (multiple regression ANOVA for repeated measures by fitting a general linear model relating cfu to dental unit, disinfection and the interaction between dental unit $x$ disinfection), not only allowed to evaluate any difference between cfu values before and after the disinfecting cycles, but also to evaluate any statistical difference in cfu between dental units and any difference between dental units in the cfu decreasing rate following the disinfecting cycles.

\section{Results}

a) DUWL mean contamination at baseline (in $\log _{10}$ ) was $5.45 \pm .35 \mathrm{CFU} / \mathrm{mL}$ (range, 4.79 to $5.93 \mathrm{CFU} / \mathrm{mL}$ ). Heterotrophic counts higher than $2.3 \log _{10} \mathrm{CFU} / \mathrm{mL}$ were found in all water samples. No significant difference in $\mathrm{CFU} / \mathrm{mL}$ was found between dental units ( $\mathrm{F}=2.17$; NS).

b) No growth of heterotrophic bacteria was detected in any of the water samples tested "in vitro" with Ster4spray. 
c) DUWL mean contamination (in $\log _{10}$ ) in water effluents from dental units which had undergone disinfecting cycles with Ster4spray was $2.01 \pm .32 \mathrm{CFU} / \mathrm{mL}$ (range 1.30 to $2.74 \mathrm{CFU} / \mathrm{mL}$ ). Heterotrophic counts higher than 2.3 $\log _{10} \mathrm{CFU} / \mathrm{mL}$ were only found in $10 \%$ of water samples. The difference in CFU/mL between values obtained after dental units had undergone disinfecting cycles and values at baseline was highly significant $(\mathrm{F}=178.8 ; \mathrm{p}<.01)$. No significant difference in $\mathrm{CFU} / \mathrm{mL}$ decreasing rate after the disinfecting cycles was found between dental units $(\mathrm{F}=$ 2.18; NS).

\section{Discussion}

Water effluents from DUWL are highly populated in routine dental practice by heterotrophic bacteria principally originating from municipal water piped to the dental unit. Human pathogens, sucked back into the lines during dental procedures due to inadequate anti-retraction on dental units, have also been reported in some studies $[3,18,19]$. Both oral pathogens and heterotrophic bacteria can be responsible for severe diseases, and immune-compromised patients in particular may be at high risk [20].

As far as heterotrophic bacteria are concerned, the results of this study confirmed that DUWL are highly contaminated when dental units in use for several months receive no decontaminating treatment. According to our data, the great amount of DUWL contamination did not greatly differ from a dental unit to another and none of the water samples collected at the beginning of randomly selected working days reached $\mathrm{CFU} / \mathrm{ml}$ values below the limit imposed by ADA for the year 2000 [4].

Interesting results have been obtained by testing the water samples against peracetic acid delivered by the chemical solution. After 5 minute of contact no growth of heterotrophic bacteria was found in any of 60 water samples tested. These results are in agreement with other reports showing that preformed peracetic acid possess a very rapid and broad spectrum microbicidal activity together with a very good activity against biofilm in waterlines used for haemodialysis [8-12].

However, despite these interesting properties, preformed peracetic acid has not been so far utilized in any study in dentistry with the aim to control DUWL contamination. Effectively, as delivered, preformed peracetic acid is unstable, potentially explosive, highly acidic and as a consequence highly corrosive. These properties make products containing preformed peracetic acid difficult to formulate for long term storage stability and difficult to handle and transport so limiting the use of this product in dentistry [9-11].
In the recent years, TAED with peroxygen source at near neutral $\mathrm{pH}$ has been clamed to provide a nonhazardous means of generating peracetic acid in situ, in the absence of the preformed peracetic acid side-effects [14].

Preliminary data from a previous study showed the relevant biocidal "in vitro" activity of the test formulation against human pathogens including spores, and data from the present study underline its great efficacy against heterotrophic bacteria both when tested "in vitro" and when flushed into DUWL [13].

In fact, DUWL flushing with the chemical solution left standing into DUWL for 5 minutes provided a good control of DUWL in all dental units studied, the mean CFU/ $\mathrm{ml}$ values being well lower than the limit imposed from ADA, and values higher than $2.3 \log _{10} \mathrm{CFU} / \mathrm{mL}$ being only detected in 6 out of 60 samples.

These data are in agreement with other studies which have obtained similar results, but adopting different disinfecting procedure [21-23], consisting of introducing chemicals into water systems either continuously or intermittently during working pauses [24-28].

Although the mentioned treatments offer less potential for recolonization of waterlines since they keep into contact the chemicals with DUWL for longer periods of time, most of these agents can not probably ensure a rapid killing of viruses and bacteria eventually sucked back during dental procedures, since they are used at very low concentration in the continuous waterline supply or during working pauses [3].

Instead, we may speculate that intermittent between-patient treatment regimens using potentially biocidal concentrations of germicide, besides keeping low level of heterotrophic bacterial counts during dental procedures, could be also effective in eliminating oral pathogens eventually aspirated from patients under dental treatment and spread out during next procedures.

For this purpose the chemical formulation tested in this study might be very useful when used between patients in combination with dental units which incorporate the capacity to disinfect DUWL by the automatic flushing of lines.

\section{Conclusions}

i)Dental unit waterlines are highly contaminated during dental procedures and aerosols generated by dental instruments are a possible source of infection;

ii)The between-patient flushing of dental unit waterlines with disinfecting solutions with strong and rapid biocidal 
activity could be very effective in controlling microbial contamination in water effluents during dental procedures.

\section{Competing interests \\ None declared}

\section{References}

I. Molinari JA: Dental infection control at the year 2000. JADA 1999, 1 30:129|-1298

2. Smith AJ, Hood J, Bagg J: Water, water everywhere but not drop to drink? Br Dent J 1999, 186:12-14

3. Walker JT, Bradshaw DJ, Bennett AM: Microbial biofilm formation and contamination of dental unit water systems in general dental practice. Appl Environ Microbiol 2000, 66:3363-3367

4. Shearer BG: Biofilm and the dental office. JADA 1996, I 27:181189

5. US Department of Health and Human Services: Recommended infection control practices for dentistry. MMWR 1993, 42:RR-8

6. Meiller TF, Depaola LG, Kelley JI: Dental unit waterlines: biofilms, disinfection and recurrence. JADA 1999, 130:65-72

7. Rutala WA, Weber DJ: Disinfection of endoscopes: review of new chemical sterilants used for high-level disinfection. Infect Control Hosp Epidemiol 1999, 20:69-76

8. Morin P: Identification of the bacteriological contamination of a water treatment line used for haemodialysis and its disinfection. J Hosp Infect 2000, 45:2 18-224

9. Griffiths PA, Babb JR, Fraise AP: Mycobactericidal activity of selected disinfectants using quantitative suspension test. J Hosp Infect |999, 4I: | II-I2I

10. Middleton AM, Chadwick MV, Gaya H: Disinfection of bronchoscopes, contaminated in vitro with Mycobacterium tubercolosis, Mycobacterium avium-intracellulare and Mycobacterium chelonae in sputum, using stabilized, buffered peracetic acid solution (Nu-Cidex). J Hosp Infect 1997, 37:137-143

II. Stanley P: Destruction of a glutaraldheyde-resistant mycobacterium by a peroxygen disinfectant. Am J Infect Control 1998, 26: 185

12. Lynam PA, Babb JR, Fraise AP: Comparison of the mycobactericidal activity of $2 \%$ alkaline glutaraldheyde and "Nu-Cidex" (0.35\% peraceti acid). J Hosp Infect 1995, 30:237-240

13. Montebugnoli L, Vasconi L, Dolci G: Evaluation of a new chemical formulation for a rapid cold sterilization of dental instruments. J Dent Res (Abstract) 20003399

14. Davis DM, Deary ME: Kinetics of the hydrolysis and perhydrolysis of teraacetylethylenediamine, a peroxide bleach activator. J Chem Soc Perkin Trans 199I, 2: 1549 I-552

15. Williams HN, Kelley J, Folineo D: Assessing microbial contamination in clean water dental units and compliance with disinfection protocol. JADA 1994, I 25: I205- I2II

16. Karpay RI, Plamondon T], Mills SE: Validation of an in-office dental unit monitoring technique. JADA 1998, 129:207-2I I

17. Williams $H N$, Quinby $H$, Romberg E: Evaluation and use of a low nutrient medium and reduced incubation temperature to study bacterial contamination in the water supply of dental units. Can J Microbiol I 994, 40:| 27-|3|

18. Montebugnoli L, Dolci G: Effectiveness of two devices designed to prevent fluid retraction in a high-speed handpiece. J Prosthet Dent 2000, 84:225-228

19. Putnins EE, Di Giovanni D, Bhullar AS: Dental unit waterline contamination and its possible implications during periodontal surgery. I Periodontol 2001, 72:393-400

20. Mills $S$ : the dental unit water controversy: defusing the myths, defining the solutions. JADA 2000, I 3 I: I 427-I450

21. Kim PJ, Cederberg RA, Puttaiah R: A pilot study of 2 methods for control of dental unit biofilms. Quintessence Int 2000, 3 I:4 I-48

22. Wirthlin MR, Marshall GW: Evaluation of ultrasonic scaling unit waterline contamination after use of chlorine dioxide mouthrinse lavage. J Periodontol 2001, 72:40I-4I0

23. Meiller TF, Kelley Jl, Baqui AA: Laboratory evaluation of anti-biofilm agents for use in dental unit waterlines. J Clin Dent 200I, I 2:97-103
24. Fayle SA, Pollard MA: Decontamination of dental unit water system: a review of current recommendations. Br Dent J 1996, 18 I: $369-372$

25. Marais JT, Brozel VS: Electro-chemically activated water in dental unit water lines. Br Dent J 1999, 187:154-I58

26. Karpay RI, Plamondon TJ, Mills SE: Combining periodic and continuous sodium hypochlorite treatment to control biofilms in dental unit water systems. JADA 1999, 130:957-965

27. Meiller T, Baqui A, DePaola L, Overholser CD: Disinfection of dental unit water lines using Listerine antiseptic. J Dent Res 1995, 74:153

28. Eleazer PD, Schuster GS, Weathers DR: A chemical treatment regimen to reduce bacterial contamination in dental waterlines. JADA 1997, I 28:617-623

Publish with BioMed Central and every scientist can read your work free of charge

"BioMedcentral will be the most significant development for disseminating the results of biomedical research in our lifetime." Paul Nurse, Director-General, Imperial Cancer Research Fund

Publish with BMC and your research papers will be: - available free of charge to the entire biomedical community - peer reviewed and published immediately upon acceptance - cited in PubMed and archived on PubMed Central

- yours - you keep the copyright 